\title{
Growth effect on liver fatty acid composition of damselfishes genus Abudefduf collected in coral reef habitats of the Malaysian South China Sea
}

\author{
Takaomi Arai ${ }^{*}$, Razikin Amalina ${ }^{1}$ and Zainudin Bachok ${ }^{2}$
}

\begin{abstract}
In order to understand feeding ecology, habitat use and migration of coral reef fish, fatty acid composition was examined in damselfish species Abudefduf bengalensis and A. sexfasciatus collected in the Malaysian South China Sea. Proportions of saturated fatty acids (SAFA) ranged from $49.5 \%$ to $74.2 \%$, with the highest proportions in fatty acids, the second highest was monounsaturated fatty acids (MUFA) ranged from $21.4 \%$ to $47.4 \%$ and the proportion of polyunsaturated fatty acids (PUFA) was the lowest ranged from 3.1\% to 6.0\%. Palmitic acid (16:0) was the most common in SAFA, oleic acid (C18:1 $19 \mathrm{c})$ was the dominant in MUFA and linolenic acid (C18:3n3) showed the highest proportion in PUFA. Fatty acid concentrations, especially in SAFA and MUFA, could be related to physiological condition, sexual development, and recent feeding events. The diet shift revealed by the fatty acid composition suggests changes in habitat use and migration scale in coral reef environment of genus Abudefduf.
\end{abstract}

Keywords: Coral fish; Diet; Habitat; Abudefduf; Migration; South China Sea

\section{Introduction}

Malaysia has one of the highest and richest diversity of fish in the world (Arai 2015). Mohsin and Ambak (1996) reported 710 species of marine fishes from the Malaysian waters and their adjacent seas. Furthermore, Ambak et al. (2010) and Chong et al. (2010) listed 2243 and 1951 fish species, respectively, in Malaysian waters. Although several information regarding taxonomy and distribution in coral fish species is available in Malaysian water, few study has done for their life history, ecology and reproduction compared to other coral reef area.

Recently, signature of fatty acid analysis has been increasingly used to study the diet of a number of marine species (e. g. Daly et al. 2010; Stowasser et al. 2012; Couturier et al. 2013). The use of fatty acids as trophic biomarkers is based on the assumption that many fatty acids in the marine environment are characteristic of specific groups (Stowasser et al. 2012). Because animals (e.g. crustaceans and fish as well as humans) cannot synthesize $\omega-3$ and $\omega-6$ fatty acids de novo, they need to

\footnotetext{
*Correspondence: arai@umt.edu.my

'Institute of Oceanography and Environment, Universiti Malaysia

Terengganu, 21030 Kuala Terengganu, Terengganu, Malaysia

Full list of author information is available at the end of the article
}

obtain these molecules from their diet, and therefore some PUFAs are considered to be essential fatty acids or 'essential nutrients' for animals (Parrish 2009). Although some mammals and freshwater fish can synthesize other forms of essential fatty acids, marine fish and freshwater zooplankton have very limited ability for bioconversion (Parrish 2009). These fatty acids can generally not be synthesized in higher trophic levels and are incorporated into tissues of higher trophic individuals (Sargent et al. 1987). Dietary fatty acids are selectively incorporated into different tissues and little is known about which tissue the profile would best mirror the diet profile of fish. It is reported that fish liver can reflect dietary fatty acid within a short timescale (10 weeks) (Beckmann et al. 2013). Thus, fish liver is suitable organ to examine the composition and the fatty acid signature can be useful to trace diet of fish in ecosystem.

The genus Abudefduf is commonly found in tropical and subtropical waters that typically occur on coral reefs (Allen 1991). Generally, the fish occurs small groups or singly having highly territorial behavior (Allen 1991; Lieske \& Myers 1994). The diet of fish is recognized algae, gastropods, and small crabs (Lieske \& Myers 1994). 
However, diet and feeding ecology of the fish is scarcely understood.

In the present study, fatty acid analyses were used to investigate the trophic ecology of damselfish species Abudefduf bengalensis and A. sexfasciatus collected in the Malaysian South China Sea. To understand the trophic position in accordance with the growth, fatty acid signatures were compared using size class samples.

\section{Material and methods}

\section{Fish}

All specimens of damselfish species Abudefduf bengalensis and A. sexfasciatus were collected at the Bidong Island in the South China Sea, Malaysia (Latitude $5.62^{\circ}$, Longitude $103.07^{\circ}$ ) between 27 and 28 October 2014 (Figure 1). Bidong Island is located off Terengganu State on the east coast of Peninsular Malaysia, known for its history as Vietnamese refugee settlement. The island also comprises of being well-developed coral reef ecosystems comprising variety of coral and rocky reef associated fishes (Matsunuma et al. 2011). All fishes were collected by means of fish traps and hook and line. After collecting, all fishes were immediately stored in ice chest, brought back to laboratory, were kept in $-20^{\circ} \mathrm{C}$ freezer and conducted fatty acid analyses within one month. A total of forty-six immature fish samples stage were measured in total length (TL), body weight (BW), and each fish was dissected, liver and the gonad removed to determine their weights (Table 1). Stomach for each fish was dissected for the content analyses.

\section{Fatty acid analysis}

Liver samples of Abudefduf bengalensis and A. sexfasciatus were analysed for fatty acid composition following the one step method (Abdulkadir and Tsuchiya 2008; Arai et al. 2015). Three replicates of each liver and tissue samples were mixed with $4 \mathrm{ml}$ of hexane and $1 \mathrm{ml}$ of internal standard solution in a $50 \mathrm{ml}$ centrifuge tube. After adding $2 \mathrm{ml}$ of $14 \%$ BF3 in methanol, the tube was flushed with nitrogen gas. The capped tube was heated on a hot plate at $100^{\circ} \mathrm{C}$ for $120 \mathrm{~min}$. One $\mathrm{ml}$ of hexane was added followed by $2 \mathrm{ml}$ of distilled water. The tube was then shaken vigorously for $1 \mathrm{~min}$ and centrifuged for $3 \mathrm{~min}$ at $2500 \mathrm{rpm}$.

Samples were then analysed using a GC-FID (GC 14-B, Shimadzu). Separation was performed with an FFAP-polar capillary column $(30 \mathrm{~m} \times 0.32 \mathrm{~mm}$ internal diameter, $0.25 \mu \mathrm{m}$ film thickness). Hydrogen was used as a carrier gas. After injection at $60^{\circ} \mathrm{C}$, the oven temperature was raised to $150^{\circ} \mathrm{C}$ at a rate $40^{\circ} \mathrm{C} \mathrm{min}{ }^{-1}$, then to $230^{\circ} \mathrm{C}$ at $3^{\circ} \mathrm{C} \mathrm{min}^{-1}$, and finally held constant for $30 \mathrm{~min}$. The flame ionization was held at $240^{\circ} \mathrm{C}$. Peaks were identified by comparing their retention times with those of authentic standards (Supelco Inc.). Fatty acids were designated as an $n: p \omega x$, where $n$ is the number of carbon atoms in the aliphatic chain, $p$ is the number of double bonds and $\mathrm{x}$ is the position of the first double bond from the terminal methyl group. The analytical precision for samples was generally $<5 \%$ for total amounts and major components.

\section{Data analyses}

Fatty acid concentrations ( $\mathrm{mg} \mathrm{g}^{-1}$ dry weight) were calculated by comparing the peak area of fatty acid in the sample with the peak area of internal standard. The percentage for each fatty acid was converted from the area of chromatogram peaks. The composition is expressed as percentage of total fatty acids (Table 2).

Differences between data were analysed using the Mann-Whitney $U$-test (Sokal \& Rohlf 1995).

\section{Results}

\section{Biological characteristics}

Abudefduf bengalensis could catagorise as either small or large according to their sizes (Table 1). Significant differences were found between two size classes in TL $(\mathrm{p}<0.0001)$, BW $(\mathrm{p}<0.0001)$ and liver weight $(\mathrm{p}<0.0001)$.

Stomach content for each fish was observed for ten randomly chosen samples. However, stomach content

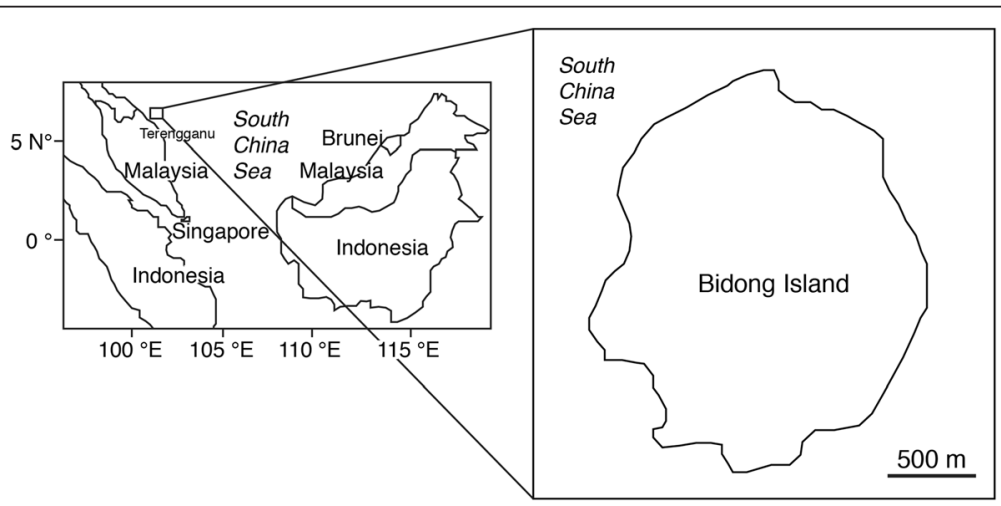

Figure 1 Map showing the location of the study site at the Bidong Island in Malaysian South China Sea, off the Terengganu State in the east coast of Peninsula Malaysia. 
Table 1 Biological information of genus Abudefduf collected in the Bidong Island Malaysian South China Sea

\begin{tabular}{|c|c|c|c|c|c|c|c|}
\hline \multirow[b]{2}{*}{ Species } & \multicolumn{2}{|c|}{ Total length $(\mathrm{cm})$} & \multicolumn{2}{|c|}{ Body weight (g) } & \multicolumn{2}{|c|}{ Liver weight (g) } & \multirow[b]{2}{*}{$\mathrm{N}$} \\
\hline & mean $\pm S D$ & range & mean $\pm S D$ & range & mean $\pm S D$ & range & \\
\hline A. bengalensis & $9.4 \pm 0.4$ & $8.5-10.1$ & $18.6 \pm 2.1$ & $14.1-23.3$ & $0.07 \pm 0.04$ & $0.02-0.20$ & 36 \\
\hline \multicolumn{8}{|l|}{ (small) } \\
\hline A. bengalensis & $14.9 \pm 0.6$ & $14.3-16.0$ & $93.0 \pm 16.8$ & $74.6-116.9$ & $1.26 \pm 0.33$ & $0.92-1.62$ & 5 \\
\hline \multicolumn{8}{|l|}{ (large) } \\
\hline A. sexfasciatus & $12.9 \pm 0.9$ & $11.3-14.4$ & $40.7 \pm 7.6$ & $31.7-53.8$ & $0.35 \pm 0.11$ & $0.15-0.49$ & 5 \\
\hline
\end{tabular}

$\mathrm{N}$ : total number of specimens.

for each fish could not identify prey organisms under macro- and micro-observations. Thus, we did not conduct stomach content observations for other 36 fishes.

\section{Difference in fatty acid composition on growth}

In Abudefduf bengalensis, fatty acid compositions were different between size groups. Proportions of saturated fatty acids (SAFA) ranged $66.7 \% 74.2 \%$, with the highest proportions in fatty acids (Table 2). Palmitic acid (16:0) was the most common saturated fatty acid ranged from $48.9 \%$ to $62.4 \%$ (Table 2) followed by C18:0 and C14:0. Significant differences in C16:0, C18:0 and SSAFA were found between small fishes (SFs) and large fishes (LFs)
( $\mathrm{p}<0.05-0.005)$, however no significant differences were found in C14:0 and C 20:0 ( $p>0.05$ ).

Monounsaturated fatty acids (MUFA) were the second dominant ranged from $21.4 \%$ to $27.3 \%$ (Table 2). Of all

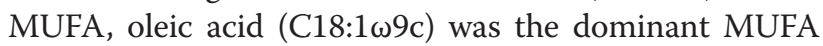
for all size classes, followed by $\mathrm{C} 16: 1$ and $\mathrm{C} 18: 1 \omega 9 \mathrm{t}$

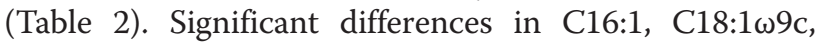
C20:1 and EMUFA were found between SFs and LFs ( $\mathrm{p}<0.05-0.0001)$, however no significant differences were found in $\mathrm{C} 17: 1$ and $\mathrm{C} 18: 1 \omega 9 \mathrm{t}(\mathrm{p}>0.05)$.

The proportion of polyunsaturated fatty acids (PUFA) was accordingly low ranged from $4.4 \%$ to $6.0 \%$ (Table 2 ). Linolenic acid showed highest ranged from $1.6 \%$ to $2.4 \%$,

Table 2 Fatty acid composition (mean \pm SD) in livers of two species of genus Abudefduf collected in the Bidong Island, Malaysian South China Sea

\begin{tabular}{|c|c|c|c|}
\hline Fatty acids & $\begin{array}{l}\text { A. bengalensis } \\
\text { small }(n=36)\end{array}$ & $\begin{array}{l}\text { A. bengalensis } \\
\text { large }(n=5)\end{array}$ & $\begin{array}{l}\text { A. sexfasciatus } \\
(\mathrm{n}=5)\end{array}$ \\
\hline \multicolumn{4}{|l|}{ SAFA } \\
\hline C14:0 & $9.1 \pm 0.7$ & $6.0 \pm 1.8$ & $4.7 \pm 0.9$ \\
\hline C16:0 & $48.9 \pm 5.3$ & $62.4 \pm 9.0$ & $43.4 \pm 8.3$ \\
\hline C18:0 & $8.2 \pm 7.6$ & $5.6 \pm 3.4$ & $1.3 \pm 1.7$ \\
\hline $\mathrm{C} 20: 0$ & $0.5 \pm 0.1$ & $0.1 \pm 0.1$ & $0.2 \pm 0.2$ \\
\hline ¿SAFA & $66.7 \pm 2.8$ & $74.2 \pm 7.8$ & $49.5 \pm 6.7$ \\
\hline \multicolumn{4}{|l|}{ MUFA } \\
\hline C16:1 & $8.6 \pm 4.2$ & $2.1 \pm 1.7$ & $8.7 \pm 2.5$ \\
\hline C17:1 & $0.4 \pm 0.3$ & $1.1 \pm 0.5$ & $0.6 \pm 0.2$ \\
\hline C18:1w9c & $8.1 \pm 1.7$ & $11.6 \pm 8.6$ & $30.3 \pm 6.5$ \\
\hline C18:1 $19 \mathrm{t}$ & $10.1 \pm 2.4$ & $6.0 \pm 6.5$ & $7.0 \pm 3.0$ \\
\hline C20:1 & $0.1 \pm 0.0$ & $0.6 \pm 0.8$ & $0.9 \pm 1.2$ \\
\hline ¿MUFA & $27.3 \pm 6.3$ & $21.4 \pm 8.0$ & $47.4 \pm 7.0$ \\
\hline \multicolumn{4}{|l|}{ PUFA } \\
\hline C18:3n3 & $2.4 \pm 1.2$ & $1.6 \pm 0.8$ & $1.4 \pm 0.2$ \\
\hline C18:3n6 & $0.6 \pm 0.3$ & $1.3 \pm 0.5$ & $0.4 \pm 0.2$ \\
\hline$C 20: 3 n 3$ & $0.1 \pm 0.1$ & $0.2 \pm 0.1$ & $0.1 \pm 0.0$ \\
\hline C20:5n3 (EPA) & $1.6 \pm 0.9$ & $1.3 \pm 0.9$ & $0.5 \pm 0.2$ \\
\hline C22:6n3 (DHA) & $1.4 \pm 2.2$ & $0.1 \pm 0.1$ & $0.6 \pm 0.7$ \\
\hline$\Sigma$ PUFA & $6.0 \pm 3.5$ & $4.4 \pm 1.5$ & $3.1 \pm 0.8$ \\
\hline Total concentration $(\mu \mathrm{g} / \mathrm{mg})$ & $143 \pm 56.9$ & $169 \pm 112$ & $273 \pm 124$ \\
\hline
\end{tabular}


followed by EPA (C20:5n3) and DHA (C22:6n3) (Table 2). Significant differences in C18:3n 3 and C20:5n 3 were found between SFs and LFs $(\mathrm{p}<0.05)$, however no significant differences were found in other combinations $(\mathrm{p}>0.05)$.

\section{Difference in fatty acid composition between species} The present study showed growth effect on fatty acid composition in Abudefduf bengalensis. Thus, similar size groups were compared between $A$. bengalensis and $A$. sexfasciatus to minimize the size effect on fatty acid composition. Proportion of SAFA in A. sexfasciatus was $49.5 \%$, with the highest proportions in fatty acids as same as A. bengalensis (Table 2). Palmitic acid was also the most common saturated fatty acid followed by C14:0 and C18:0. Significant differences in C16:0, C18:0 and ISAFA were found between those species $(\mathrm{p}<0.05$ 0.01 ), however no significant differences were found in C14:0 and C 20:0 ( $\mathrm{p}>0.05)$.

MUFA were also the second dominant in A. sexfasciatus (Table 2). Oleic acid was the dominant MUFA,

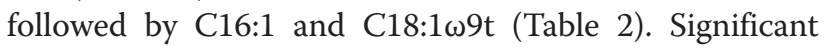
differences in C16:1, C18:1 $\omega 9 \mathrm{c}$ and $\Sigma$ MUFA were found between species $(p<0.01-0.0005)$, however no significant

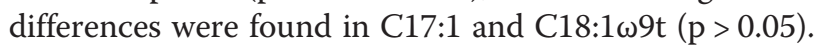

The proportion of polyunsaturated fatty acids (PUFA) was the lowed averaging 3.1\% (Table 2). Linolenic acid showed highest, followed by EPA and DHA (Table 2). A significant difference in C18:3n6 were found between species $(p<0.05)$, however no significant differences were found in other combinations $(\mathrm{p}>0.05)$.

Total fatty acid concentrations ranged from 143 to $273 \mu \mathrm{g} \mathrm{mg}^{-1}$ (Table 2). No significant differences were found in all combinations ( $\mathrm{p}>0.05)$.

\section{Discussion}

It is noteworthy that fatty acid composition was different depending on the size groups in a damselfish species Abudefduf bengalensis. Differences in individual fatty acid profiles were reported previously with various factors such as development (Legendre et al. 1995; Soivio et al. 1989), food habits (Daly et al. 2010; Stowasser et al. 2012; Couturier et al. 2013) and habitat use (De Silva et al. 1997; Takeuchi \& Watanabe 1982; Tidwell et al. 1992), temperature (Takeuchi \& Watanabe 1982) and salinity (Borlongan and Benitez 1992; De Silva et al. 1997). Although the mechanism of lipid deposition in the liver of fish fed diets was still uncertain, fatty acid synthesis was regulated by liver $\mathrm{X}$ receptor suggesting the profiles of the liver reflected diets of fish (Peng et al. 2014). The low amount PUFA was found in the present study. In particular, it has been reported that PUFA is able to limit triglyceride deposition in the liver (Xin et al. 2008; Di Minno et al. 2012), whereas a diet deficient in n-3 PUFA with a high $n-6 / n-3$ ratio could induce fatty liver (El-Badry et al. 2007). However, differences in fatty acid composition and levels in relation to body size in wild fish species have not been well reported. It is likely that such differences are caused by differences in the diet, behavior and migration of the damselfish accompanying the growth. The fish were found in coastal and mangrove area during the life (Allen 1991; Lieske \& Myers 1994; Matsunuma et al. 2011) The role of mangroves as nursery habitats for some coral fish species has received considerable attention as a link with adjacent coral reef or offshore habitats (e.g. Beck et al. 2001; Parrish 1989; Pollard 1984). The diet shifts of coral reef fish species that inhabit mangroves have been reported their early life stages (Cocheret de la Morinie' re et al. 2002; Nagelkerken et al. 2000; Cocheret de la Morinie' re et al. 2003). These findings suggest that differences in fatty acid profile during growth found in the present study might correspond to the diet and habitat shifts in A. bengalensis.

SAFA was the most abundant fatty acids and the palmitic SAFA showed highest values among all fatty acids (Table 2). The second most abundant SAFA was stearic acid. These two SAFAs have been reported to have the highest concentrations in other fish species (Elsdon 2010; Sahena et al. 2009), Acetes (Montaño et al. 2001) and in copepods (van der Meeren et al. 2008). The predominance of both fatty acids has been attributed to their use as a major source of energy for metabolism and growth (Sargent et al. 2002). Fishes from warm waters tend to show high levels of palmitic and stearic acids compared to those from cold waters. This difference is due to metabolic differences between cold and warm water species, because these fatty acids are not usually subject to differences in diet (Huynh \& Kitts 2009). Damselfish species Abudefduf bengalensis and A. sexfasciatus were collected in the South China Sea in tropical waters, and thus the fish might have higher palmitic and stearic acid levels in the present study.

MUFA was the second most abundant fatty acids, with highest values for oleic acid (Table 2). This is in agreement with findings in copepod (Olivotto et al. 2010), Acetes (Montaño et al. 2001) and fish fatty acid profiles (Elsdon 2010; Huynh and Kitts 2009; Sahena et al. 2009; Sirot et al. 2008). Oleic MUFA is naturally occurring in large concentrations in many marine organisms, which can also synthesise this MUFA de novo (Sargent et al. 2002). High proportions of MUFAs of marine predators are generally derived from marine zooplankton (Pond \& Tarling 2011; Pond et al. 2012). In the present study, we did not conduct fatty acid analyses for potential prey organisms. Nevertheless, the higher level of MUFAs found in Abudefduf bengalensis and A. sexfasciatus suggest that the fish might feed copepod as one of potential prey organism during the life history. 
Fatty acid signature has been increasingly used to study the diet of a number of marine species. The present study suggests that diets of the coral fish species Abudefduf bengalensis and $A$. sexfasciatus changed in accordance with growth. Furthermore, differences in fatty acid profiles might not just be considered with respect to the diets, but might be based on the habitat and migration.

\section{Ethical standards}

This study has been conducted in a field station at the Bidong Island belonging to Universiti Malaysia Terengganu. This study was also reviewed and approved by the Universiti Malaysia Terengganu ethics board.

\section{Competing interests}

The authors declare that they have no competing interests.

\section{Authors' contributions}

RA performed the filed survey and experiments described in this study. ZB supervised the experiments described in this study. TA performed the filed survey, supervised the experiments, analyzed the data and wrote the manuscript. All the authors read and approved the final manuscript.

\section{Acknowledgements}

The authors are grateful to staffs in Universiti Malaysia Terengganu for their kind assistance with the field survey. This work was supported by the Higher Institution Centre of Excellence (HICoE) Research Grant (Vot No. 66928), under the Institute of Oceanography and Environment (INOS).

\section{Author details}

${ }^{1}$ Institute of Oceanography and Environment, Universiti Malaysia Terengganu, 21030 Kuala Terengganu, Terengganu, Malaysia. ${ }^{2}$ School of Marine Science and Environment, Universiti Malaysia Terengganu, 21030 Kuala Terengganu, Terengganu, Malaysia.

Received: 11 December 2014 Accepted: 29 January 2015

Published online: 10 February 2015

\section{References}

Abdulkadir S, Tsuchiya M (2008) One-step method for quantitative and qualitative analysis of fatty acids in marine animal samples. J Exp Mar Biol Ecol 354:1-8 Allen GR (1991) Damselfishes of the World. Mergus Publishers, Germany, p 271 Ambak MA, Isa MM, Zakaria MZ, Ghaffar MA (2010) Fishes of Malaysia. Universiti Malaysia Terengganu, Kuala Terengganu, 334 pp

Arai T (2015) Diversity and conservation of coral reef fishes in the Malaysian South China Sea. Rev Fish Biol Fisheries doi:10.1007/s11160-014-9371-9

Arai T, Amalina R, Bachok Z (2015) Similarity in the feeding ecology of parrotfish (Scaridae) in coral reef habitats of the Malaysian South China Sea, as revealed by fatty acid signatures. Biochem System Ecol 59:85-90, doi:10.1016/j. bse.2015.01.011

Beck MW, Heck KL, Able KW, Childers DL, Eggleston DB, Gillanders BM, Halpern B, Hays CG, Hoshino K, Minello TJ, Orth RJ, Sheridan PF, Weinstein MP (2001) The identification, conservation, and management of estuarine and marine nurseries for fish and invertebrates. Bioscience 51:633-642

Beckmann CL, Mitchell JG, Seuront L, Stone DA, Huveneers C (2013) Experimental evaluation of fatty acid profiles as a technique to determine dietary composition in benthic elasmobranchs. Physiol Biochem Zool 86:266-278

Borlongan IG, Benitez LV (1992) Lipid and fatty acid composition of milkfish (Chanos chanos Forsskal) grown in freshwater and seawater. Aquaculture 104:79-89

Chong VC, Lee PKY, Lau CM (2010) Diversity, extinction risk and conservation of Malaysian fishes. J Fish Biol 76:2009-2066

Cocheret de la Morinie' re E, Pollux BYA, Nagelkerken I, van der Velde G (2002) Post-settlement life cycle migration patterns in relation to biotope preference of coral reef fish that use seagrass and mangrove habitats as nurseries. Estuar Coast Shelf Sci 55:309-321
Cocheret de la Morinie' re E, Pollux BJA, Nagelkerken I, van der Velde G (2003) Diet shifts of Caribbean grunts (Haemulidae) and snappers (Lutjanidae) and the relation with nursery-to-coral reef migrations. Estuar Coast Shelf Sci 57:1079-1089

Couturier LIE, Rohner CA, Richardson AJ, Marshall AD, Fabrice RA, Jaine FRA, Bennett MB, Townsend KA, Weeks SJ, Nichols PD (2013) Stable isotope and signature fatty acid analyses suggest reef manta rays feed on demersal zooplankton. PLoS ONE 8(10):e77152

Daly EA, Cassandra E, Benkwitt CB, Brodeur RD, Litz MNC, Copeman LA (2010) Fatty acid profiles of juvenile salmon indicate prey selection strategies in coastal marine waters. Mar Biol 157:1975-1987

De Silva ASS, Gunasekera RM, Austin CM (1997) Changes in the fatty acid profiles of hybrid red tilapia, Oreochromis mossambicus $X 0$. niloticus, subjected to short-term starvation, and a comparison with changes in seawater raised fish. Aquaculture 153:273-290

Di Minno MN, Russolillo A, Lupoli R, Ambrosino P, Di Minno A, Tarantino G (2012) Omega-3 fatty acids for the treatment of non-alcoholic fatty liver disease. World J Gastroenterol 18:5839-5847

El-Badry AM, Graf R, Clavien PA (2007) Omega 3 - Omega 6: What is right for the liver? J Hepatol 47:718-725

Elsdon TS (2010) Unraveling diet and feeding histories of fish using fatty acids as natural tracers. J Exp Mar Biol Ecol 386:61-68

Huynh MD, Kitts DD (2009) Evaluating nutritional quality of pacific fish species from fatty acid signatures. Food Chem 114:912-918

Legendre M, Kerdchuen N, Corraze G, Bergot P (1995) Larval rearing of an African catfish Heterobranchus longifilis (Teleostei, Claridae): effect of dietary lipids on growth, survival and fatty acid composition of fry. Aquat Living Resour 8:355-363

Lieske E, Myers R (1994) Collins Pocket Guide. Coral reef fishes. Indo-Pacific \& Caribbean including the Red Sea. Haper Collins Publishers, New York, USA, p 400

Matsunuma M, Motomura H, Matsuura K, Shazili NAM, Ambak MA (2011) Fishes of Terengganu East coast of Malay Peninsula, Malaysia., National Museum of Nature and Science, Tokyo, Universiti Malaysia Terengganu, Terengganu, and Kagoshima University Museum, Kagoshima p 251

Mohsin AKM, Ambak MA (1996) Marine fishes and fisheries of Malaysia and neighbouring countries. Agriculture University of Malaysia Press, Serdang, p 744

Montaño N, Gavino G, Gavino VC (2001) Polyunsaturated fatty acids of some traditional fish and shrimp paste condiments of the Philippines. Food Chem 75:155-158

Nagelkerken I, Dorenbosch M, Verberk WCEP, Cocheret de la Morinie' re E, van der Velde G (2000) Importance of shallowwater biotopes of a Caribbean bay for juvenile coral reef fishes: patterns in biotope association, community structure and spatial distribution. Mar Ecol Prog Ser 202:175-192

Olivotto I, Tokle NE, Nozzi V, Cossignani L, Carnevali O (2010) Preserved copepods as a new technology for the marine ornamental fish aquaculture: A feeding study. Aquaculture 308:124-131

Parrish JD (1989) Fish communities of interacting shallow-water habitats in tropical oceanic regions. Mar Ecol Prog Ser 58:143-160

Parrish CC (2009) Essential fatty acids in aquatic food webs. In: Arts MT, Brett MT, Kainz MJ (eds) Lipids in aquatic ecosystems. Springer, Dordrecht, The Netherlands, pp 309-326

Peng M, Xu W, Mai K, Zhou H, Zhang Y, Liufu Z, Zhang K, Ai Q (2014) Growth performance, lipid deposition and hepatic lipid metabolism related gene expression in juvenile turbot (Scophthalmus maximus L.) fed diets with various fish oil substitution levels by soybean oil. Aquaculture 433:442-449

Pollard DA (1984) A review of ecological studies on seagrass-fish communities, with particular reference to recent studies in Australia. Aquat Bot 18:3-42

Pond DW, Tarling GA (2011) Phase transitions of wax esters adjust buoyancy in diapausing Calanoides acutus. Limnol Oceanogr 56:1310-1318

Pond DW, Tarling GA, Ward P, Mayor D (2012) Wax ester composition influences the diapause patterns in the copepod, Calanoides acutus. Deep-Sea Res II 59-60:93-104

Sahena F, Zaidul ISM, Jinap S, Saari N, Jahurul HA, Abbas KA, Norulaini NA (2009) PUFAs in fish: Extraction, fractionation and importance in health. Comp Rev Food Sci Food Saf 8:59-74

Sargent JR, Parkes JR, Mueller-Harvey I, Henderson RJ (1987) Lipid biomarkers in marine ecology. In: Sleigh MA (ed) Microbes in the sea. Ellis Horwood Ltd., Chichester, pp 119-138 
Sargent JR, Tocher DR, Bell JG (2002) The lipids. In: Halver JE, Hardy RW (eds) Fish nutrition, 3rd edn. Academic Press, San Diego, pp 181-257

Sirot V, Oseredczuk M, Bemrah-Aouachria N, Volatier JL, Leblanc JC (2008) Lipid and fatty acid composition of fish and seafood consumed in France: CALIPSO study. J Food Comp Anal 21:8-16

Soivio A, Niemisto M, Backstrom M (1989) Fatty acid composition of Coregonus muksun Pallas: Changes during incubation, hatching, feeding and starvation. Aquaculture 79:163-168

Sokal RR, Rohlf FJ (1995) Biometry, 3rd edn. Freeman and Company, New York Stowasser G, Pond DW, Collins MA (2012) Fatty acid trophic markers elucidate resource partitioning within the demersal fish community of South Georgia and Shag Rocks (Southern Ocean). Mar Biol 159:2299-2310

Takeuchi T, Watanabe T (1982) The effects of starvation and environmental temperature on proximate and fatty acid composition of carp and rainbow trout. Bull Jpn Soc Sci Fish 48:1307-1316

Tidwell JH, Webster CD, Clark JA (1992) Effects of feeding, starvation, and refeeding on the fatty acid composition of channel catfish tissues. Comp Biochem Physiol 103A:365-368

van der Meeren T, Olsen RE, Hamre K, Fyhn HJ (2008) Biochemical composition of copepods for evaluation of feed quality in production of juvenile marine fish. Aquaculture 274:375-397

Xin YN, Xuan SY, Zhang JH, Zheng MH, Guan HS (2008) Omega-3 polyunsaturated fatty acids: a specific liver drug for non-alcoholic fatty liver disease (NAFLD). Med Hypotheses 71:820-882

Submit your manuscript to a SpringerOpen ${ }^{\circ}$ journal and benefit from:

- Convenient online submission

- Rigorous peer review

- Immediate publication on acceptance

- Open access: articles freely available online

- High visibility within the field

- Retaining the copyright to your article

Submit your next manuscript at $\gg$ springeropen.com 